\title{
VOORDRAG
}

\section{vir die toekenning van die graad Doctor Educationis, honoris causa, aan prof. dr. Jan Waterink.}

Die Raad en die Senaat het op hul vergaderinge in November 1954 besluit om aan prof. dr. Jan Waterink, gebore 20 Oktober 1890, die graad Doctor Educationis honoris causa toe te ken.

Vier oorweginge het tot die besluit gelei.

Prof. Waterink word in Suid-Afrika erken as een van die trouste vriende van die Afrikaanse volk. Met sy besoek aan Suid-Afrika gedurende 1949 (van Februarie tot Junie) het hy hom betoon as 'n uitnemende vriend in sy akademiese en sosiale optrede. Na sy terugkeer het hy sy indrukke van ons land aan die pers meegedeel, en die strekking daarvan was heelhartige waardering vir ons land en volk. Voor en na sy besoek 
aan Suid-Afrika was en is hy die goeie vriend van alle Afrikaanse studente in Nederland en van so baie besoekers uit ons land aldaar. Dit het hy gedoen nie om geëer te word nie maar uit suiwere liefde en waardering vir die Afrikaner.

Prof. Waterink was in al die jare van sy diens as professor aan dic „Vrije Universiteit" 'n medestryder met die P.U.K. vir C.H.O. vir die beoefening van die wetenskap op Christelike grondslag. Die Potchefstroomse Inrigting het in hom 'n goeie ondersteuner gehad. Een blyk daarvan is die onbaatsugtige leiding wat hy gee aan studente uit SuidAfrika in die wetenskappe Opvoedkunde en Sielkunde. Een van ons professore, dr. D. C. S. du Preez, het onder hom gepromoveer, 'n ander professor, dr. J. M. Hattingh, gaan vanjaar aan prof. Waterink se Kliniek navorsinngswerk doen, en een van ons senior lektore, dr. C. F. Schoeman, het so pas onder hom as sielkundige gepromoveer. Prof. Waterink het ook in 1952 met die driehonderdjarige fees van ons volksplanting die promotorskap waargeneem in verband met die toekenning van 'n credoktoraat aan ons eerste Rektor, prof. dr. J. C. van Rooy.

Prof. Waterink was vroeër en is vanjaar weer die Rector Magnificus van die „Vrije Universiteit". Die feit dat prof. Waterink die diensdoende Rektor van die "Vrije Universiteit" is in die loop van tie jaar van sy groot jubileum, was nie van gewig ontbloot by die besluit van ons Raad en Senaat nie. Die Potchefstroomse Universiteit wou as blyk van sy waardering, hoogagting en liefde vir die „Vrije Universiteit” aan dic huidige Rektor aldaar dieselfde eer bewys as wat die „Vrije Universiteit" in 1952 aan ons Rektor bewys het.

Maar, die Raad en die Senaat het by oorweging van watter doktorsgraad toegeken moet word, die wetenskaplike prestasie van prof. Waterink die deurslag laat gee. Jan Waterink is sinds 8 Oktober 1926 verbind aan die „Vrije Universiteit” as professor in die Pedagogiek, die Psigologic, die Kindersielkunde en die Kategetiek. Sinds die aanvaarding van sy professoraat het hy ' $n$ wêreldnaam as wetenskaplike op die trebied van die Opvoedkunde en Sielkunde verwerf. Daartoe het bygedra sy geskrifte in boek- en artikelvorm, en ook sy stigtinge: „Paedagogisch Instituut” en "Laboratorium voor Toegepaste Psychologie". Onder sy groot werke moet genoem word veral sy vierdelige standaardwerk: „Inleiding tot de Paedagogiek als Wetenskap". Onder sy meer populêre en bekend geworde werke val veral "Aan moedershand tot Jezus” en „Met moeder bij Jezus". Besonder invloedryk het ook geword sy "De oorsprong en het wezen der Ziel” en „Ons Zieleleven”. Wat sy artikels betref, kan net gekonstateer word dat hulle versprei lê oor baie tydskrifte, sommige 
waarvan hy opgerig het, andere waarvan hy die hoofredakteur is. Ek noem net: „Moeder”, „Paedagogisch Tijdschrift voor het Christelijk Onderwijs" "Efficiency en Documentasie".

In 1949 het hy Suid-Afrika op uitnodiging besoek en oor die breedte en lengrte van ons land inspirerende voordragte gelewer oor opvoedkundig- sielkundige probleme. In 1954 was hy op 'n soortgelyke reis in die Verenigde State en het as gevolg daarvan 'n boek gepubliseer „Basic Concepts in Christian Pedagogy".

Hier is 'n mens, 'n vriend, 'n volksman, 'n leier, 'n wetenskaplike aan wie enige universiteit met vrymoedigheid en op goeie gronde 'n eredoktoraat kan toeken.

Dit is nou, mnr. die Kanselier, vir my 'n voorreg en 'n genoeë om u te versoek om die hoë onderskeiding van Doctor Educationis, honoris causa toe te ken aan prof. dr. Jan Waterink van die "Vrije Universiteit", Ansterdam.

J. CHR. COETZEE,

Promotor. 